\title{
PBL based Teaching-learning Strategy for Inculcating Research Aptitude in CS/IT Students
}

\author{
Amol C. Adamuthe ${ }^{1 *}$, Sandeep U. Mane ${ }^{2}$ \\ ${ }^{1,2}$ Rajarambapu Institute of Technology, Rajaramnagar, Sangli, MS, India \\ 1 amol.admuthe@gmail.com \\ ${ }^{2}$ manesandip82@gmail.com
}

\begin{abstract}
The student engagement with developing problem-solving, self-learning and research aptitude is a challenging assignment in higher education especially in engineering education. Various outcome-based teachinglearning methodologies devised by educationalist and practised by engineering teachers. The main objective of this paper is to develop problem-solving, self-learning and research aptitude among students using problem-based learning (PBL). To achieve the objectives, the backward design process is used. Paper presents the PBL process from finalizing objectives, assessment methods, curriculum and instructional activities for inculcating research aptitude. Paper presents the activities for two selected courses, advanced algorithm and soft computing. Course outcomes of selected courses address the higher level of Bloom's taxonomy. Paper elaborates the teaching activities, evaluation mechanism and attainment of outcomes of courses. Higher attainment of course outcomes reflects the improvement in student's academic performance. Students' feedback reflects the satisfaction for course conduction and PBL activities.
\end{abstract}

Keywords: Problem based learning (PBL), active learning methods, research aptitude, outcome-based education.

\section{Introduction}

The higher education, especially the engineering education system is now in the transition phase. Engaging students for the complete course or a single session of a course is a big challenge in front of engineering teachers. The new entrant as a teacher in engineering education is not well prepared to engage and teach engineering students (Collaco, 2017). Today to teach any course, merely subject matter expert is not sufficient, effective teaching strategies are also important. The traditional teaching methods do not promote the active participation of learners. The traditional teaching-learning process is ineffective to promote thought and change the attitude of learners. It also deficit to teach behavioural skills to students (Gentelli, 2015). As opposed to traditional teaching-learning methods, the active learning tools help to increase learners focus and attention towards learning, it promotes learner engagement, critical thinking and joy of learning.

\section{Corresponding Author: Amol C. Adamuthe}

Rajarambapu Institute of Technology, Rajaramnagar, Sangli, MS, India. amol.admuthe@gmail.com

Different learning resources are available through various means. There exist various active teaching-learning techniques such as project-based learning, problem-based learning, Jigsaw, think pair share, brainstorming. Problembased learning is a promising technique implemented from school levels to higher education (Butler, 1998). The primary goal of PBL is to enhance learning by requiring learners to solve problems. It gives learner real-world experience. Problem-based learning makes use of complex real-world problems to improve the learning of different concepts. The problem solving is important for learners to become effective problem solvers in their profession, and for later career success (Mazumder, 2014). Problem-based learning is focusing on problems in which learners can construct their own knowledge, develop inquiry and thinking skills to a higher level.

The main objective of this study is to use problem-based learning to develop problem-solving, self-learning abilities and research aptitude among students. To achieve this objective backward design process is used. In the backward design process, goals are finalized before assessment techniques and curriculum.

Step 1: Set objectives

The main objective is divided into sub-divided as follows:

- Objective 1: Analyse complex engineering/real-life problems using fundamental mathematics and algorithms.

- Objective 2: Design efficient solutions to solve complex problems considering the given constraints.

- Objective 3: To adapt recent techniques, algorithms, data structures for efficiently solving problems.

- Objective 4: To undertake original research in the computing domain.

Step 2: Assessment methods

- Problem-based method

- Presentation of case study

- Written exam

- Online discussion forum

Step 3: Curriculum and instructional methods 
This paper presents an application of problem-based learning for inculcating research aptitude in computer science and engineering students. To achieve the objectives, we have identified one course from semester I and one course from semester II of first-year M. Tech CSE programme in the same academic year. The first course is the advanced algorithm and the second course is soft computing. The advanced algorithm course deals with solving a variety of problems using traditional techniques. This course covers various problem-solving techniques such as divide and conquer, dynamic programming, etc. Soft computing methods mimic consciousness and cognition in several aspects. The soft computing course aims to make the student proficient to apply various emerging problem-solving methodologies such as machine learning, evolutionary algorithms, neural networks etc.

Section 2 presents related work. The planning phase of the implementation of problem-based learning discussed in Section 3. Section 4 presents the assessment methods planned. Curriculum design and instructional activities are presented in Section 5. The course outcome attainments and students' feedback are discussed in Section 6. Conclusion of the study presented in section 7 .

\section{Related Work}

This section briefs about the problem-based learning technique from literature.

The Problem-Based Learning (PBL) is a teaching-learning pedagogy that centres student learning on open-ended and student-driven problems. An instructor facilitates the PBL in order to achieve the learning outcomes of a course.

Problem-based learning has the following advantages (Major \& Palmer, 2001; Gallagher, 1997; Vernon \& Blake, 1993; Woods et al., 2000).

- Encourages self-directed learning and improves student independence.

- Helps to promote long-term knowledge as well as skill retention, which gained during the PBL.

- Motivates critical thinking and interdisciplinary problem-solving.

- Encourages the application of theory/knowledge to solve real-world problems.

- Increases group effort among students.

- Improves soft skills, specially written and verbal communication skill of the student.

A primary assumption of PBL is that "when we solve the many problems we face every day, learning occurs" (Barrows \& Tamblyn, 1980).

The problem-based learning (PBL) is one of the innovative active learning method implemented by teachers in mainly the medical field. The heart of this method is an improvement in problem-solving and self-directed learning skills, which was widely reported in the medical education field (Barrows \& Tamblyn, 1980; Schmidt, 1983). PBL has also become increasingly popular across disciplines in higher education and $\mathrm{K}-12$ education settings. The PBL reported in the literature with different perspectives (Barrows, 2000; Dochy et al., 2003; Gallagher et al., 1992; Hmelo-Silver, 2004; Evensen et al., 2000; Torp \& Sage, 2002; Hmelo \& Williams, 1998). Table 1 presents the school type and problem addressed using PBL.

Table 1: School type and problem addressed using PBL

\begin{tabular}{|l|l|}
\hline School type & Nature of the problem addressed \\
\hline Medical schools & $\begin{array}{l}\text { To solve diagnosis-solution problems } \\
\text { (Collaço, 2017) }\end{array}$ \\
\hline Law schools & $\begin{array}{l}\text { To learn to construct arguments based on } \\
\text { evidentiary reasoning (Collaço, 2017) }\end{array}$ \\
\hline Computer science & $\begin{array}{l}\text { Life-long learning skill required in Project } \\
\text { work (Ellis et al., 1998) }\end{array}$ \\
\hline Computer science & $\begin{array}{l}\text { To improve student's commitment and } \\
\text { reduce the dropout rate (Ellis et al., 1998) }\end{array}$ \\
\hline Computer science & $\begin{array}{l}\text { To engage students in rigorous problem- } \\
\text { solving and critical thinking (Fee \& Holland- } \\
\text { Minkley, 2010) }\end{array}$ \\
\hline
\end{tabular}

Ellis et al. (1998) have argued that problem-based learning is especially well suited to computer science. Computing discipline matches the characteristics of problem-based learning as computing itself is mostly problem-driven. As the life-long learning skill is a necessity of this domain, the professionals must update their skills regularly (Ellis et al., 1998).

The Hamalainen (2004) have experimented the problembased teaching-learning approach to teach the theory of computability. According to the author, the selected methodology was first experimented to teach a completely theoretical course in computer science. The outcome of the selected methodology was quite impressive. The student's commitment was improved and the dropout rate reduced. Students able to achieve a deep understanding of the subject, which was measured based on students obtained grade and quality of learning diaries. As the learners have supported the method, both, teachers and students, enjoyed the implementation (Hamalainen, 2004).

Teachers in computer science and engineering field, irrespective of his/her course try to engage students in rigorous problem-solving and critical thinking (Fee \& Holland-Minkley, 2010).

In literature, the implementation of PBL varies. Woods et al. (2000) presented different variations of PBL.

\section{Problem Based Learning: Planning Phase}

This section presents the planning phase of the problembased learning for selected two courses.

The relevant program outcomes for $\mathrm{M}$. Tech computer science and engineering program are as follows.

After completion of the computer engineering program, students should be able to: 
- PO1: An understanding of the theoretical foundations and the limits of computing.

- PO2: An ability to adapt existing models, techniques, algorithms, data structures, etc. for efficiently solving problems.

- PO3: An ability to design, develop and evaluate new computer-based systems for novel applications that meet the desired needs of industry and society.

- PO4: An ability to undertake original research at the cutting edge of computer science $\&$ its related areas.

- PO5: Understanding and ability to use advanced computing techniques and tools.

\section{A. Course learning outcomes of AA}

This course makes students aware of algorithms, design techniques and application areas. In this course, design paradigms explored in greater depth and more advanced techniques for solving computational problems presented. This course contains different algorithm design techniques, NP-hard \& complete problems, approximation algorithms and heuristic algorithms. The focus of the course is to understand the basics and recent trends of an algorithm.

On successful completion of the advanced algorithm course, students should be able to:

- CO1: Select appropriate algorithm design techniques such as divide and conquer, greedy method, dynamic programming and approximation algorithms.

- $\quad \mathrm{CO} 2$ : Implement and evaluate graph-based algorithms.

- CO3: Solve linear programming problems.

- CO4: Explore NP problems. Compare traditional and Metaheuristic algorithms.

- CO5: Identify the new trends and research directions in algorithms.

Table 2 presents the CO-PO mapping for advanced algorithm course. The dense mapping matrix indicates the high correlation of course outcomes to the first five program outcomes. All the designed course outcomes are strongly correlated to the four objectives of this study explained in the introduction section.

Table 2. CO-PO mapping for AA course

\begin{tabular}{|l|l|l|l|l|l|}
\hline & PO1 & PO2 & PO3 & PO4 & PO5 \\
\hline CO1 & High & High & High & High & - \\
\hline CO2 & High & High & - & High & High \\
\hline CO3 & High & High & - & - & High \\
\hline CO4 & High & - & High & High & - \\
\hline CO5 & - & - & High & High & - \\
\hline
\end{tabular}

B. Course learning outcomes of SC

Soft computing is a discipline that deals with the design of intelligent systems, which are in contrast to classical hard computing techniques. The principal objective of this course is to introduce students to soft computing techniques from a computer science perspective. It covers fuzzy logic, neural networks and evolutionary algorithms. These techniques help to achieve tractable, robust, and low-cost solutions to real-world problems.

By the end of the soft computing course, students should be able to:

- CO1: Describe various soft computing techniques.

- $\quad \mathrm{CO} 2$ : Identify and design fuzzy-based systems.

- CO3: Design a neural network for real-world application.

- CO4: Identify and compare evolutionary techniques with traditional techniques.

- CO5: Explore different selection, crossover and mutation operators of genetic algorithms.

- CO6: Apply evolutionary computation techniques to optimization, forecasting etc.

Table 3 presents the CO-PO mapping for soft computing course. The dense mapping matrix indicates the high correlation of course outcomes to the first five program outcomes. All the designed course outcomes are strongly correlated to the four objectives of this study explained in the introduction section.

Table 3. CO-PO mapping for AA course

\begin{tabular}{|l|l|l|l|l|l|}
\hline & PO1 & PO2 & PO3 & PO4 & PO5 \\
\hline CO1 & High & High & - & High & - \\
\hline CO2 & High & High & - & High & - \\
\hline CO3 & High & High & High & High & High \\
\hline CO4 & - & - & High & High & High \\
\hline CO5 & - & - & High & High & - \\
\hline CO6 & - & High & High & High & - \\
\hline
\end{tabular}

\section{Problem Based Learning: Assessment methods}

This section discusses the outcomes achieved after implementation of PBL for selected courses.

A. Bloom's Level Addressed

Bloom's taxonomy is the most popular model to classify learning objectives in education. The learning objectives are classified into different levels based on complexity.

Bloom's levels are as follows- level 1- Remembering, level 2- Understanding, level 3- Applying, Level 4- Analysing, Level 5- Evaluating and Level 6- Creating.

Evaluation of selected two courses in done with respect to Bloom's levels.

In incremental fashion, we are focusing on higher levels of Bloom's taxonomy. The advanced algorithm course focus on Level 3, Level 4 and Level 5 of Bloom's taxonomy. The fundamentals of mathematics and algorithms used to design algorithms, which solves efficiently the real-world problems. 
The soft computing course focus on Level 3 to Level 6 of Bloom's taxonomy. The recent problem-solving techniques such as machine learning, genetic algorithms, fuzzy logic, and neural networks applied to solve the real world and research-based optimization and forecasting problems.

\section{B. Evaluation modes and steps}

Table 3 and Table 4 presents the mapping of a mode of evaluations to course outcomes (CO) for the course advanced algorithm and soft computing respectively. The problems assigned in a group of 2-4 students. The students have a choice to implement algorithms/soft-computing methods to solve the mathematical or real-world problems using $\mathrm{C}$ or $\mathrm{C}++$ or Java or MATLAB.

Table 3. Correlation between mode of evaluations and CO mapping for an advanced algorithm course

\begin{tabular}{|l|l|l|}
\hline Evaluation & \multicolumn{1}{|c|}{ Mode } & \multicolumn{1}{c|}{ Course outcome } \\
\hline $\begin{array}{l}\text { Online discussion } \\
\text { forum }\end{array}$ & Individual & $\mathrm{CO} 1, \mathrm{CO} 5$ \\
\hline Problem solving & Team & $\mathrm{CO} 1, \mathrm{CO} 3, \mathrm{CO} 4, \mathrm{CO} 5$ \\
\hline $\begin{array}{l}\text { Presentation of case } \\
\text { study }\end{array}$ & Team & $\mathrm{CO} 1, \mathrm{CO} 2, \mathrm{CO} 4, \mathrm{CO} 5$ \\
\hline $\begin{array}{l}\text { Written evaluation } \\
\text { Individual }\end{array}$ & $\begin{array}{l}\mathrm{CO} 1, \mathrm{CO} 2, \mathrm{CO} 3, \mathrm{CO} 4, \\
\mathrm{CO} 5\end{array}$ \\
\hline
\end{tabular}

Table 4. Correlation between mode of evaluations and CO mapping for soft computing course

\begin{tabular}{|l|l|l|}
\hline \multicolumn{1}{|c|}{ Mode of Evaluation } & Mode & Course outcome \\
\hline Online discussion forum & Individual & CO1,CO2, CO5 \\
\hline Problem solving & Team & $\begin{array}{l}\mathrm{CO} 2, \mathrm{CO} 3, \mathrm{CO} 4, \\
\mathrm{CO} 5, \mathrm{CO} 6\end{array}$ \\
\hline $\begin{array}{l}\text { Implantation of soft } \\
\text { computing method for } \\
\text { selected problems }\end{array}$ & Team & $\begin{array}{l}\mathrm{CO} 2, \mathrm{CO}, \mathrm{CO} 4, \\
\mathrm{CO} 5, \mathrm{CO} 6\end{array}$ \\
\hline $\begin{array}{l}\text { Written evaluation } \\
\text { f }\end{array}$ & Individual & $\begin{array}{l}\mathrm{CO} 1, \mathrm{CO} 2, \mathrm{CO} 3, \\
\mathrm{CO} 4, \mathrm{CO} 5, \mathrm{CO} 6\end{array}$ \\
\hline
\end{tabular}

- Online discussion forum- This evaluation is carried out using a Moodle platform. Mentor uploads the problembased questions on Moodle. Each student is expected to answer these questions.

- Problem-solving, presentation of case study and Implementation of soft computing method

The steps to complete the work in the team is as follows:

Phase 1: Mentor/instructor decides the area of research in line with the course curriculum. List the objectives of problems and maps with course outcomes. Decides the evaluation strategy.

Phase 2: Collecting resource material and preliminary study.

Students collect research articles from academic journals or conferences or magazines for a given topic. Students spend 2-3 days' time to list different problems in the given area.

Phase 3: Topic finalization

Students finalize the topic in discussion with the mentor/instructor. As per the guidelines presented by (Dunkhase \& Penick, 1990; Cordeiro \& Campbell, 1995) the selected topics must be complex and illustrate real-world scenarios.

Phase 4: Analysing the problem

- Jot down the problem. Identify 2-3 papers attempted the same problem.

- Identify real-world/engineering applications for the basic building block problem

- Identify the strategy used to solve the problem

- Compare the different strategies used in different papers.

- Identify the research gap.

Phase 5: Report writing and presentation

Students prepare and submit the report. Students present their finding to a class.

Table 5 shows the assessment rubrics used for the evaluation of students assignments.

Sample topics completed for advanced algorithm course are presented in Table 6.

Table 6. Sample PBL topics for an advanced algorithm course

\begin{tabular}{|l|l|}
\hline $\begin{array}{l}\text { Dynamic programming for } \\
\text { solving 01 knapsack problem }\end{array}$ & $\begin{array}{l}\text { Applications of the Greedy } \\
\text { method }\end{array}$ \\
\hline Graph colouring problem & $\begin{array}{l}\text { Improving the efficiency of } \\
\text { the backtracking algorithm to } \\
\text { solve the Queen problem }\end{array}$ \\
\hline Branch and bound method & Reduction of NP problems \\
\hline $\begin{array}{l}\text { Branch and bound method for } \\
\text { solving Travelling salesperson } \\
\text { problem }\end{array}$ & $\begin{array}{l}\text { Backtracking for solving } \\
\text { constraints satisfaction } \\
\text { problem }\end{array}$ \\
\hline $\begin{array}{l}\text { Approximation algorithm for } \\
\text { solving Travelling salesperson } \\
\text { problem }\end{array}$ & $\begin{array}{l}\text { Travelling } \\
\text { problem using Branch and } \\
\text { Bound }\end{array}$ \\
\hline Set cover problem & Vertex cover problem \\
\hline
\end{tabular}

Sample topics completed for soft computing course presented in Table 7.

Table 7. Sample PBL topics for soft computing course

\begin{tabular}{|l|l|}
\hline $\begin{array}{l}\text { Multidimensional Knapsack } \\
\text { Problem }\end{array}$ & Naive Bayes Algorithm \\
\hline Bin Packing problem & $\begin{array}{l}\text { ANN for solving time } \\
\text { series forecasting problems }\end{array}$ \\
\hline Hill Climbing method & Tabu Search \\
\hline Firefly Algorithm & Cuckoo search algorithm \\
\hline $\begin{array}{l}\text { Travelling salesperson problem } \\
\text { Approximation problem }\end{array}$ & Ant Colony Optimization \\
\hline $\begin{array}{l}\text { Flower pollination algorithm } \\
\text { Fuzzy logic }\end{array}$ & $\begin{array}{l}\text { Teaching Learning Based } \\
\text { Optimization }\end{array}$ \\
\hline
\end{tabular}




\begin{tabular}{|l|l|}
\hline $\begin{array}{l}\text { Study of Membership Function } \\
\text { and Fuzzy rules on Air } \\
\text { Conditioning system }\end{array}$ & $\begin{array}{l}\text { Spam Email Classification } \\
\text { \& Washing Machine Fuzzy } \\
\text { Logic }\end{array}$ \\
\hline $\begin{array}{l}\text { Forest Fire Detection in Wireless } \\
\begin{array}{l}\text { Sensor Network Using Fuzzy } \\
\text { Logic }\end{array}\end{array}$ & $\begin{array}{l}\text { Traffic Signal Control } \\
\text { Using Fuzzy Logic }\end{array}$ \\
\hline
\end{tabular}

List of techniques implemented by the students for advanced algorithm and soft computing course.

- A greedy method, Dynamic programming, Backtracking

- $\quad$ Linear programming

- Approximation algorithm

- Fuzzy logic, Artificial neural network, Random Forest Algorithm, Genetic algorithms

Table 5. Assessment Rubrics

\begin{tabular}{|c|c|c|c|c|c|}
\hline \multirow{2}{*}{$\begin{array}{l}\text { Sr. } \\
\text { No. }\end{array}$} & \multirow{2}{*}{ Criteria } & \multicolumn{4}{|c|}{ Level of Attainment } \\
\hline & & Poor & Satisfactory & Good & Excellent \\
\hline 1 & $\begin{array}{l}\text { Identify area, sub- } \\
\text { area and topic }\end{array}$ & $\begin{array}{l}\text { Identified area, sub- } \\
\text { area and topic are not } \\
\text { relevant. }\end{array}$ & $\begin{array}{ll}\text { Identified } & \text { domain } \\
\text { relevant to current } \\
\text { trends / fundamental } \\
\text { question. }\end{array}$ & $\begin{array}{l}\text { - Identified domain } \\
\text { relevant to current } \\
\text { trends/fundamental } \\
\text { question. } \\
\text { - Identified correct sub- } \\
\text { area. }\end{array}$ & $\begin{array}{lr}\text { Identified } & \\
\text { topic/problem } & \text { is } \\
\text { conceptually correct } \\
\text { and uses correct } \\
\text { technical terminology. }\end{array}$ \\
\hline 2 & $\begin{array}{l}\text { Depth of literature } \\
\text { review }\end{array}$ & $\begin{array}{l}\text { - Insufficient papers } \\
\text { are selected. } \\
\text { - Identified papers are } \\
\text { not from good } \\
\text { journals. }\end{array}$ & $\begin{array}{l}\text { - Selected a good } \\
\text { number of papers } \\
\text { from } \\
\text { journals. } \\
\text { - Standard } \\
\text { Selected papers focus } \\
\text { on similar objectives. }\end{array}$ & $\begin{array}{l}\text { - A good number of } \\
\text { papers are reviewed. } \\
\text { - Written critical } \\
\text { comments. } \\
\text { - Identified research } \\
\text { gap. }\end{array}$ & $\begin{array}{l}\text { - Identified more than } \\
\text { one research gap. }\end{array}$ \\
\hline 3 & $\begin{array}{l}\text { Problem statement } \\
\text { and objectives }\end{array}$ & $\begin{array}{l}\text { Problem statement and } \\
\text { objectives are not clear } \\
\text { and inline }\end{array}$ & $\begin{array}{l}\text { Identified problem } \\
\text { statement and objectives } \\
\text { are clear and inline }\end{array}$ & $\begin{array}{l}\text { Problem statements and } \\
\text { objectives are according } \\
\text { to the research gap }\end{array}$ & $\begin{array}{l}\text { Problem statements and } \\
\text { objectives address } \\
\text { multiple research gaps. }\end{array}$ \\
\hline 4 & Critical thinking & $\begin{array}{l}\text { Not analysed the } \\
\text { problem and problem- } \\
\text { solving approaches. }\end{array}$ & $\begin{array}{l}\text { Analysed the problem } \\
\text { and one problem- } \\
\text { solving approach. }\end{array}$ & $\begin{array}{l}\text { Identified variation in } \\
\text { problem statements and } \\
\text { objectives. Compared to } \\
\text { different problem- } \\
\text { solving approaches. }\end{array}$ & $\begin{array}{l}\text { Critical analysis of } \\
\text { objectives and problem- } \\
\text { solving approaches. }\end{array}$ \\
\hline 5 & $\begin{array}{l}\text { Presentation Skills \& } \\
\text { Report Quality }\end{array}$ & $\begin{array}{l}\text { Poor PPT quality and } \\
\text { presentation skills } \\
\text { PPT / Report content is } \\
\text { incomplete or } \\
\text { incorrect. }\end{array}$ & $\begin{array}{l}\text { Technical mistakes in } \\
\text { the content. } \\
\text { The report is not } \\
\text { technically correct and } \\
\text { comprehensive. }\end{array}$ & $\begin{array}{l}\text { Quality of PPT is good } \\
\text { and technically correct. } \\
\text { The report is technically } \\
\text { correct and } \\
\text { comprehensive }\end{array}$ & $\begin{array}{l}\text { Quality of PPT is good } \\
\text { and technically correct. } \\
\text { Content is presented } \\
\text { with proper flow and } \\
\text { convincing skills } \\
\text { The report is technically } \\
\text { correct and } \\
\text { comprehensive } \\
\text { No grammatical } \\
\text { mistakes and typo } \\
\text { errors in presentation } \\
\text { and report. }\end{array}$ \\
\hline
\end{tabular}

\section{Problem Based Learning: Teaching-learning Phase}

This section discusses the teaching-learning phase of problem-based learning.

Identify the core concepts of the course in line with the course outcomes.

\section{A. Core concepts of Course}

Core concepts of advanced algorithm course are as follows.

- Exact algorithms

- Approximate algorithms

- Heuristic algorithms
- Graph-based techniques

- $\quad \mathrm{P}$ and NP problems

- Constraint satisfaction problem

- Optimization problems

- The time complexity of an algorithm

- Basic problems- Traveling salesperson problem, bin packing problem, queen problem

Core concepts of soft computing course are as follows.

- Applications of soft computing 
- Fuzzy system

- Artificial neural network

- Genetic algorithm

- Swarm intelligence

- Optimization algorithms

- Heuristic/meta-heuristic algorithms

B. Teaching strategies

To achieve the learner's engagement, various active teaching-learning tools/methodologies used to deliver the course content.

- Problem-based learning

The problem-based learning is about to learn the various concepts of a course by solving open-ended problems. It helps to develop knowledge gaining, enhanced teamwork and communication

- Demonstration based learning

The demonstration based learning involves explaining any concept with proof or using examples or showing any experiment.

- Case study

The case study based teaching involves engaging learners working on complex and real-world problems. It helps the learner to solve the problem with critical thinking.

- Presentation

The presentation-based approach allows learners to solve the problem and present the idea or solution. It helps to improve communication skill at large.

- Team-based learning

In team-based learning (TBL), the learner has more responsibility. The learner has to coordinate and communicate with team members to develop a solution and present it.

The sample problems selected for problem-based learning of course advanced algorithm presented here.

- Identify applications of divide and conquer algorithm.

- Comment on: Divide and conquer design technique is not applicable to solve Travelling salesperson problem.

- Identify two algorithms with divide and conquer technique to solve the minimum cost spanning tree problem.

- Identify the minimum number of platforms required for a railway/bus station. Design a greedy algorithm.

- Design a greedy algorithm to find the minimum number of coins.

- Elaborate the greedy strategy used in process scheduling algorithms: First come first serve and Round robin
- Elaborate the greedy strategy used in bin packing algorithms: First fit and best fit.

- Illustrate the limitations of a greedy method with $0 / 1$ knapsack problem.

- Illustrate the limitations of a greedy method with the graph colouring problem.

- Illustrate the limitations of a greedy method with shortest path problem.

- Differentiate between fractional knapsack problem and 0/1 knapsack problem.

- Impact of state-space tree on the performance of the backtracking algorithm.

- Discuss the importance of solution representation with respect to satisfying constraints of the problem.

- Design 1D and 2D solution representation for solving queen problem.

- Differentiate P and NP problem with examples.

- Identify real-world applications of vertex cover problem. Discuss approximation algorithm for solving vertex cover problem.

- Illustrate the philosophy behind metaheuristic algorithms. Why these algorithms are popular to solve optimization problems?

- Identify the limitations of traditional algorithms to solve the constraint satisfaction problem.

The sample questions for problem-based learning for soft computing course presented here.

- Which are the main streams of soft computing?

- Discuss the different definitions of soft computing.

- Which genetic algorithm operator performs exploitation?

- Identify different scientific and business workflows applications.

- Differentiate Evolutionary algorithms from traditional algorithms.

- Compare steady-state Genetic algorithms (GA) with standard GA.

- Explore the impact of different parameters on the performance of a neural network.

- Identify two real-world applications where fuzzy logic is beneficial.

- What is the importance of membership function in fuzzy logic?

- List swarm algorithms. What is the motivation behind particle swarm optimization?

- How Teaching learning-based optimization (TLBO) is different from Particle swarm optimization (PSO)? 
- Suggest solution representation for Travelling salesperson problem.

- Differentiate between scheduling, timetabling and rostering.

- Differentiate between class timetabling and exam timetabling.

- List real-world scheduling and timetabling applications.

- List different ways of soft computing to improve the solutions of a class timetabling problem.

- List two engineering problems that need Global optimization techniques instead of local optimization techniques.

- What is swarm algorithms?

- What is the motivation behind particle swarm optimization?

\section{Discussion}

This section presents course outcome attainments and student's feedback on PBL.

\section{A. Course Outcomes Attainments}

At the end of instruction activity and after the completion of all the evaluation of respective courses, the course outcomes attainment has calculated.

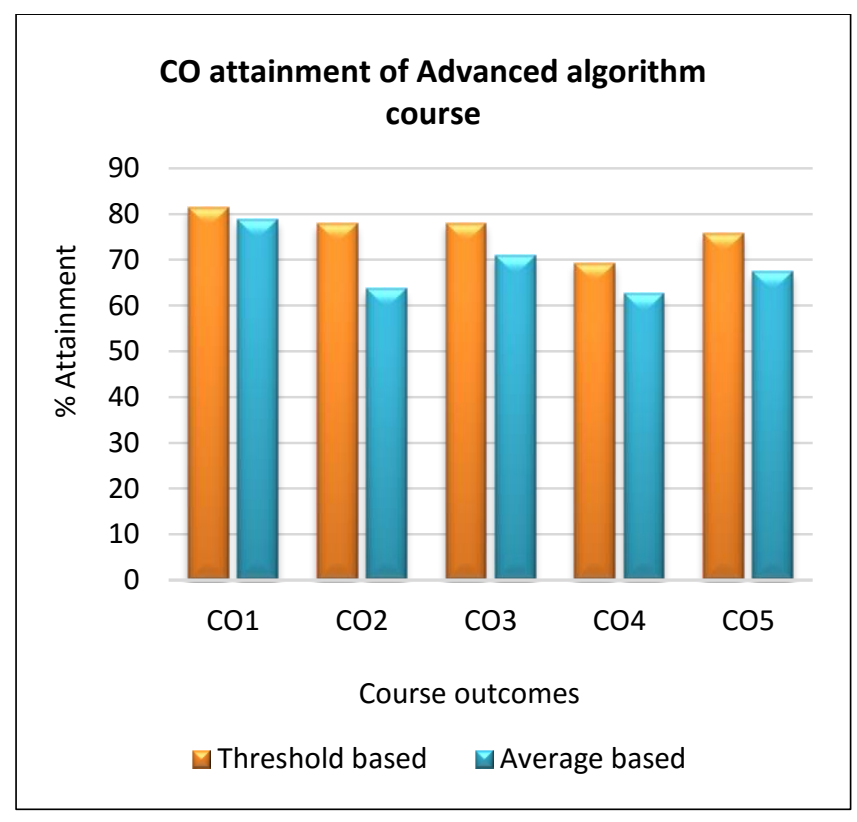

Fig. $1 \mathrm{CO}$ attainment of advanced algorithm course

The course outcome attainment is calculated using two methods
i. Threshold-based attainment
ii. Average based attainment

The used formulas for course outcome attainment are described in equation 1 and 2 .
Threshold based Attainment $\%=(x / y) * 100$

where,

$\mathrm{x}=$ Number of students obtained marks greater than the threshold

$\mathrm{y}=$ Total number of students appeared for the course

The threshold value for $\mathrm{CO}$ attainment decided at the beginning of the semester. The threshold decided based on average marks of the previous year(s) for the respective course.

Average based Attainment $\%=(x / y) * 100$

$\mathrm{x}=$ Average marks obtained by appeared students $\mathrm{y}=$ Maximum marks

Fig. 1 presents the course outcome attainment of advanced algorithm course. For advanced algorithm course, thresholdbased course outcome attainment is better than average based. Higher values of threshold-based course attainment indicate that current semester students' performance is better than previous years. Average based attainment for all course outcomes except $\mathrm{CO} 2$ and $\mathrm{CO} 4$ is better than $65 \%$. Course attainment of $\mathrm{CO} 2$ and $\mathrm{CO} 4$ is approximately $63 \%$.

Observations for AA course:

- $\quad$ Majority of students does the selection of appropriate exact technique to solve a given problem.

- $\quad$ Most of the students have identified good problems. Selected good research papers and presented the case study.

- $\quad$ Difficulties in designing chronological backtracking and its variations for solving real-world scheduling problems

- Difficulties in effectively applying branch and bound algorithm

- Challenges in the reduction of NP problems

- Challenges in designing effective solution representation and objective function for solving optimization problems 


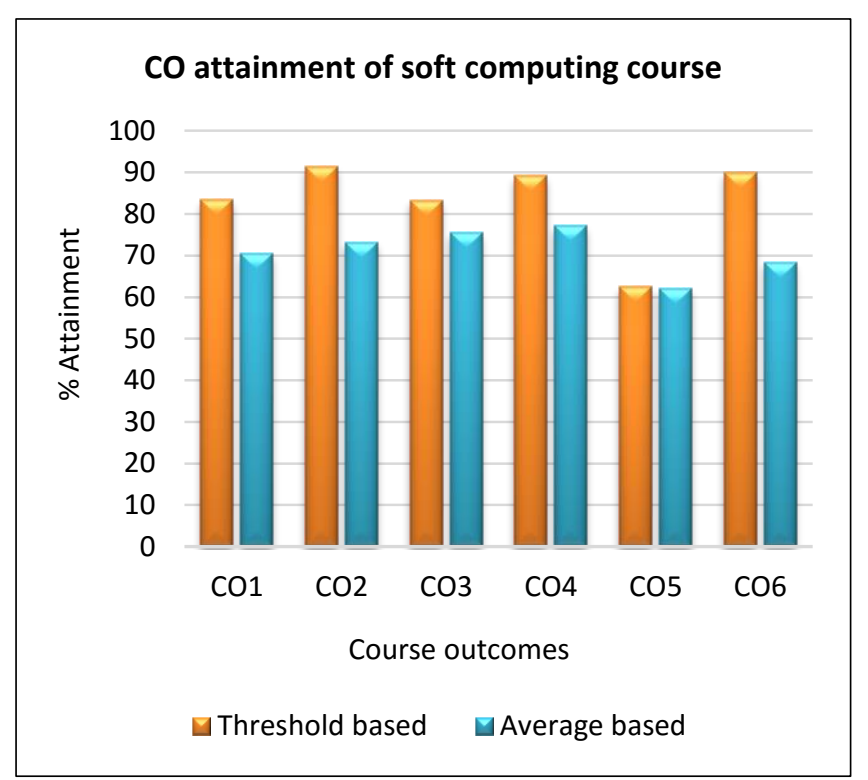

Fig. $2 \mathrm{CO}$ attainment of soft computing course

Fig. 2 presents the course outcome attainment of soft computing course. For advanced algorithm course, threshold-based course outcome attainment is better than average based. Higher values of threshold-based course attainment indicate that current semester students' performance is better than previous years. Average based attainment for all course outcomes except $\mathrm{CO} 5$ and $\mathrm{CO} 6$ is better than $70 \%$. Course attainment of CO5 and CO6 is approximately $62 \%$ and $68 \%$ approximately.

Observations for SC course:

- Majority of students investigate fuzzy systems for real-world or engineering applications.

- $\quad$ Identified real-world optimization and forecasting problems.

- $\quad$ Challenges in identifying appropriate crossover and mutation operators of genetic algorithms to solve realworld problems.

- Challenges in designing problem-specific genetic algorithms operators.

\section{Student Feedback for Course Conduction}

Table 8 presents the student feedback questionaries and respective weightages. Equal weightage is given to each question. The maximum score for each point is 1.43 . The range for students feedback is from 1 to 10 . Value 1 indicates lower end and value 10 indicates the higher end.

Table 8. Questionaries for student feedback

\begin{tabular}{|l|l|l|}
\hline $\begin{array}{l}\text { Sr. } \\
\text { no. }\end{array}$ & Questionnaires & $\begin{array}{l}\text { Maximum } \\
\text { score }\end{array}$ \\
\hline 1 & Were the course content made clear to you & 1.43 \\
\hline 2 & $\begin{array}{l}\text { Do you feel that the complex topics were } \\
\text { made simple during teaching }\end{array}$ & 1.43 \\
\hline 3 & $\begin{array}{l}\text { Do you get opportunities for raising doubts } \\
\text { within and outside the classroom }\end{array}$ & 1.43 \\
\hline 4 & $\begin{array}{l}\text { Are enough confidence and interest getting } \\
\text { created in the course }\end{array}$ & 1.43 \\
\hline
\end{tabular}

\begin{tabular}{|l|l|l|}
\cline { 3 - 3 } 5 & $\begin{array}{l}\text { Are all course components and Evaluations } \\
\text { challenging }\end{array}$ & 1.43 \\
\hline 6 & $\begin{array}{l}\text { Are you given enough opportunities for } \\
\text { learning by doing }\end{array}$ & 1.43 \\
\hline 7 & $\begin{array}{l}\text { Are you able to connect the content learnt } \\
\text { (theory) to outside Practices (Application) }\end{array}$ & 1.42 \\
\hline
\end{tabular}

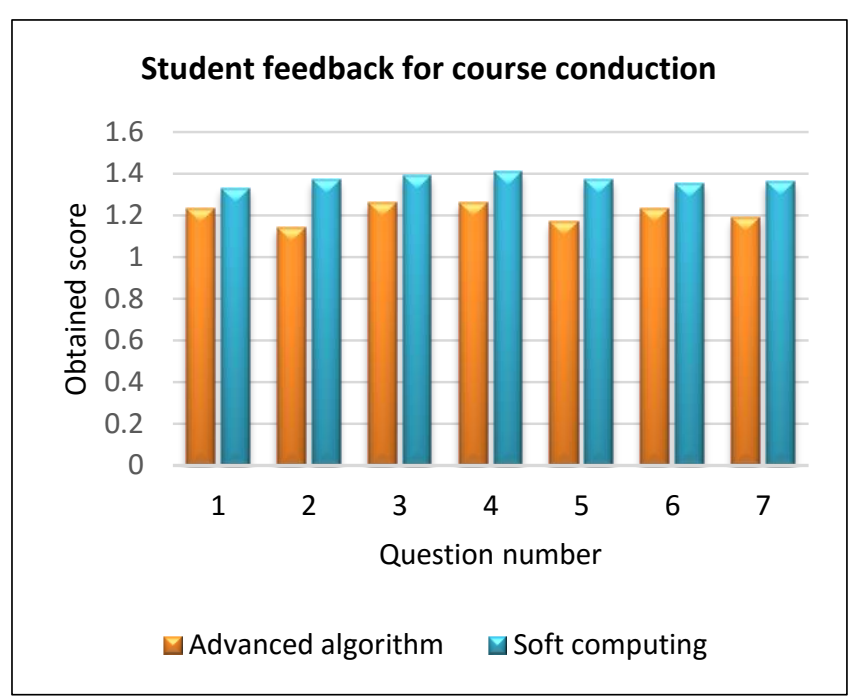

Fig. 3 Student feedback for course conduction

Fig. 3 presents student feedback after completion of course in the respective semester. The obtained score for all questions for advanced algorithm course is near to 1.2 value. The obtained score for all questions for soft computing course is near to 1.36 value.

\section{B. Observations of PBL strategies}

\section{1) Students' Feedback on PBL implementation}

This sub-section presents students' feedback on PBL implementation. Fig. 4 presents the students' feedback on the effectiveness of PBL activities. Students are satisfied with PBL activities. The PBL activities conducted was challenging and it helped to improve critical analysis and problem solving skills. To solve problems, it requires integration of concepts from different domains. The theoratical knowledge is applied to complex real world engineering problems.

2) Advantages of problem-based learning

After implementing the PBL, we have found advantages of this method. Similar advantages are also reported in the literature.

- The critical thinking level of the student has improved while identifying suitable problem-solving approach and designing the solution, as well as it shows the improvement in research aptitude.

- The PBL motivates students to apply the concept learned during theory class such as algorithms and data structures to solve real-world problems.

- The PBL helped the student to do self-directed and selfmotivated study. 
- The coordination and cooperation among a group of student improved, which will help them to work effectively in a diverse group of people in their profession.

- As the implementation phase, consist of preparing a report and presenting it to class, the PBL helped to improve the verbal and non-verbal communication skill of the student.

- Personalized Learning: Teacher/mentor can give personalized feedback on assessments of each group.

- It helped to inculcate life-long learning skill among students.

3) Challenges in implementing PBL

After implementing the PBL, we have found a few challenges.

- $\quad$ Student's mindset - as like traditional teaching-learning process some of the students expects that, instructor/mentor must provide the information required to solve the problem. In the initial period, students rely on the existing solution to the problem.

- Active involvement of all group members - it has observed that in some groups, not all the members are participating actively. The implementation of PBL for slow students is challenging. These students take more time to get the desired outcomes.
If the teacher successfully overcomes the PBL implementation challenges, the PBL is one of the active learning technique that can practised to achieve the listed objectives.

\section{Conclusions}

Problem-based learning is one of the most suitable approaches to develop problem-solving, self-learning and research aptitude skill sets among students. This paper presented the implementation of problem-based learning activities for two courses namely advanced algorithm and soft computing. Paper presented the backward design approach. PBL activities from outcomes, assessment phase and course designing are presented. The core concepts, detailed instructional strategies and evaluation methods discussed in this paper.

Course outcome attainments are calculated using threshold and average based methods. Attainments indicate that students performance is improved. Students' feedback is taken for course conductions and PBL activity planning. Students are satisfied with the course conduction and PBL activities.

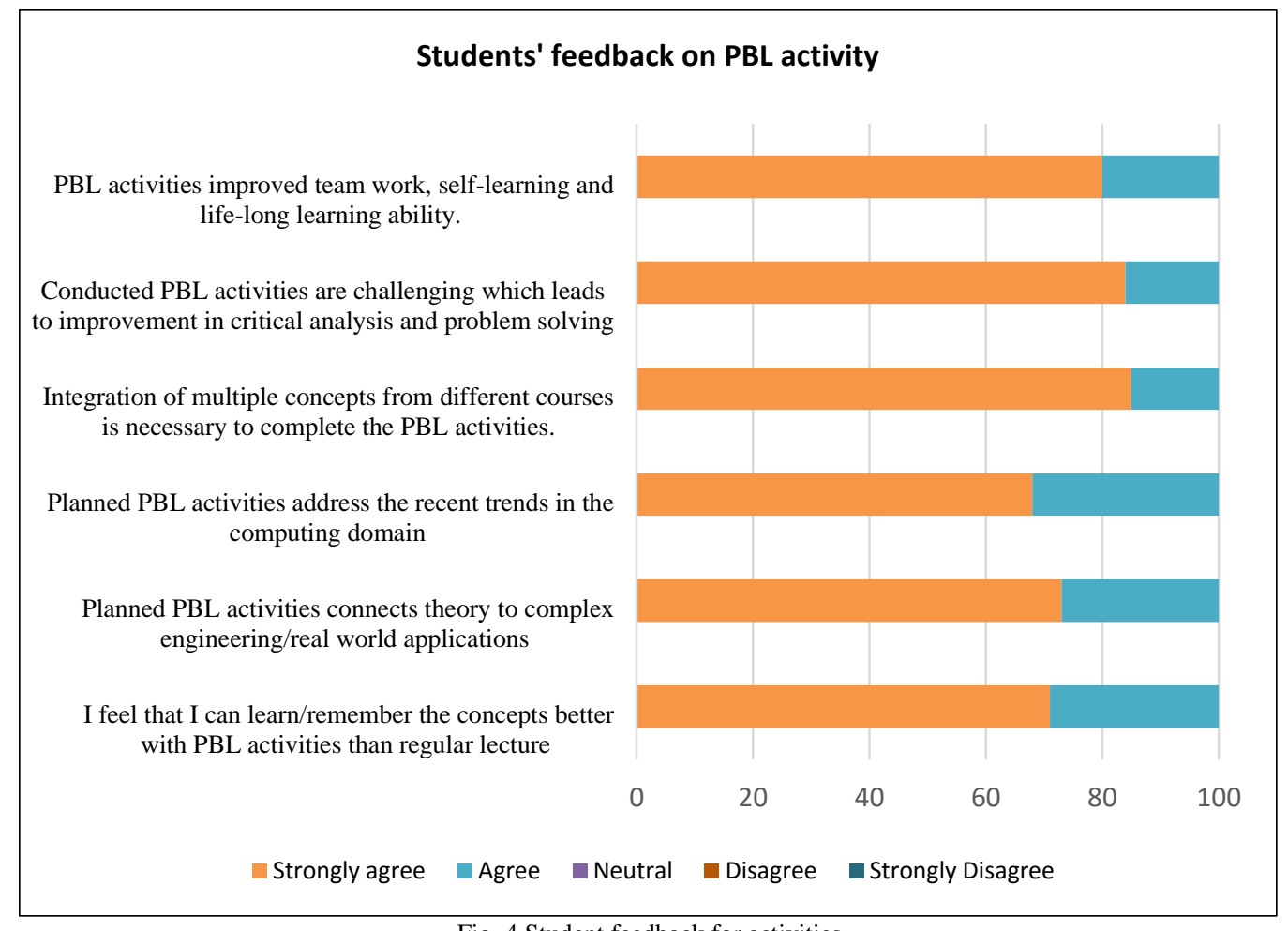

Fig. 4 Student feedback for activities

\section{References}

Barrows, H. S. (2000). Problem-based learning applied to medical education. Southern Illinois University School of Medicine.
Barrows, H. S., \& Tamblyn, R. M. (1980). Problem-based learning: An approach to medical education. Springer Publishing Company.

Butler, S. M. (1998). The Process of Problem-Based Learning: A Literature Review. Journal of Health Occupations Education, 13(1), 9. 
Collaço, Christine M. "Increasing student engagement in higher education." Journal of Higher Education Theory and Practice 17, no. 4 (2017)

Cordiero, P. A., \& Campbell, B. (1996). Increasing the Transfer of Learning through Problem-Based Learning in Educational Administration.

Dochy, F., Segers, M., Van den Bossche, P., \& Gijbels, D. (2003). Effects of problem-based learning: A meta-analysis. Learning and instruction, 13(5), 533-568.

Dunkhase, J.A. \& Penick, J.E. (1990). Problem solving in the real world. Journal of College Science Teaching, 19(6), 367-370.

Ellis, A., Carswell, L., Bernat, A., Deveaux, D., Frison, P., Meisalo, V., Meyer, J., Nulden, U., Rugeji, J., \& Tarhio, J. (1998, December). Resources, tools, and techniques for problem based learning in computing. In Working Group reports of the 3rd annual SIGCSE/SIGCUE ITiCSE conference on Integrating technology into computer science education (pp. 41-56). ACM.

Evensen, D. H., Hmelo, C. E., \& Hmelo-Silver, C. E. (2000). Problem-based learning: A research perspective on learning interactions. Routledge.

Fee, S. B., \& Holland-Minkley, A. M. (2010). Teaching computer science through problems, not solutions. Computer Science Education, 20(2), 129-144.

Gallagher, S. A. (1997). Problem-based learning: Where did it come from, what does it do, and where is it going? Journal for the Education of the Gifted, 20(4), 332-362.

Gallagher, S. A., Stepien, W. J., \& Rosenthal, H. (1992). The effects of problem-based learning on problem solving. Gifted Child Quarterly, 36(4), 195-200.

Gentelli, L. (2015). Using industry professionals in undergraduate teaching: Effects on student learning. Journal of University Teaching \& Learning Practice, 12, 1-11.

Hamalainen, W. (2004, October). Problem-based learning of theoretical computer science. In 34th Annual Frontiers in Education, 2004. FIE 2004. (pp. S1H-1). IEEE.

Hmelo, C. E., \& Williams, S. M. (1998). Learning through problem solving. Erlbaum.

Hmelo-Silver, C. E. (2004). Problem-based learning: What and how do students learn?. Educational psychology review, 16(3), 235-266.

Major, C. H., \& Palmer, B. (2001). Assessing the effectiveness of problem-based learning in higher education:
Lessons from the literature. Academic exchange quarterly, 5(1), 4-9.

Mazumder, Q., (2014). Student motivation and learning strategies of students from usa, china and bangladesh, International Journal of Evaluation and Research in Education (IJERE), 3(4), 205-210

Schmidt, H. G. (1983). Problem-based learning: Rationale and description. Medical education, 17(1), 11-16.

Torp, L., \& Sage, S. (2002). Problem as Possibilities, Problem Based Learning for K-16. USA: Association for Supervision and Curriculum Development.

Vernon, D. T., \& Blake, R. L. (1993). Does problem-based learning work? A meta-analysis of evaluative research. Academic medicine.

Woods, D. R., Felder, R. M., Rugarcia, A., \& Stice, J. E. (2000). The future of engineering education III. Developing critical skills. change, 4, 48-52. 